\title{
Transportation Cost Reduction and Simulation of Entire Flow Process along with Value Stream Mapping
}

\section{U. Mohamed Faizal* and V. Ajith}

Department of Mechanical Engineering, Sri Shakthi Institute of Engineering and Technology, Coimbatore, Tamil Nadu, India

ABSTRACT: The article is about to reduce the transportation cost of an outsourcing component which has the main usage for testing. It involves five sub-contractors in order to complete the required demand. A main contractor whose job is to manufacture valves for various customers will outsource some of its work with these sub-contractors. A simple linear programming model is constructed mathematically with the supply and demands as constraints. This model is used to optimize the transportation cost by following the shortest distance from each source to destination which results about Rs.17270 for the entire supply chain on a day. The overall flow process is simulated which results in the number of components produced per day is 64 . A value stream map is drawn for the current state of the industry and it is improvised with some alternatives to reduce the lead time and increase the productivity in the future state mapping. By this alternatives the lead time is reduce from 431.60 minutes to 345.20 minutes and the Non-Value Added Time is reduced from 1.60 minutes to 20 seconds.

KEYWORDS: Transportation, Process Simulation, Solver, Value Stream Mapping.

(C) 2017 mahendrapublications.com, All rights reserved

\section{INTRODUCTION}

\subsection{Transportation}

The efficiency of transportation is one of the most important factors for supply chain management. For this reason, many companies develop various strategies to boost customer satisfaction and bring down the total costs. Transportation problem is an optimization problem which aims at the optimal distribution of the quantities from sources to destinations to minimize the total cost [1]. A traditional transportation model consists of an objective function and two kinds of constraints, namely source constraint and destination constraint. In these classical models, the unit costs of transportation, the supplies and the demands were supposed to be crisp numbers [2].

Quantitative models and mathematical tools such as linear programming allows for better result. We can use modern computing equipment for this purpose. Nowadays various problems of operational planning for transportation problems are solved by mathematical methods. Linear programming method is used to model most of these transportation problems [3]. The problem of minimization of the total transportation cost is commonly treated in literature as a basic single objective linear transportation model. The transportation time is relevant in a variety of real transportation problems too [4].

Considering the various complexity in real world, some researchers were aware of a fact that it was usually inappropriate to regard the unit costs of transportation, the supplies and the demands as crisp numbers and considered as variables. It is recommended to take the single DC and the regional central stock strategies for slow moving and demanding products respectively: Minimizing inventory \& transportation cost of an industry: a supply chain optimization [5]. In practice, though the unit costs of transportation and the demands are uncertain, the supplier might usually predict the distribution capacities of the supply according to statistical data of production capacity over years [6]. Thus, for the supplier, capacities of the supply are regarded as random variables. For the above reasons, the main aim of this article is to study a transportation model with various supplies and uncertain demands.

\subsection{Flow Process in Manufacturing System}

A manufacturing system comprises manufacturing equipment arranged in certain fashion. Many manufacturing equipment exists for the implementation of basic discrete manufacturing processes into production machinery. The different types of manufacturing system are discussed below. These systems have a physical layout while intangible production control operates on production philosophies [7]. In industry sectors, it is important to manufacture the products which have good quality products and meet customers demand. This action could be conducted under existing resources such as employees, machines and other facilities [8]. Other important elements of the manufacturing systems are methods of information, energy, and material transfer. The physical layout of the discrete manufacturing systems is normally divided into two areas:

1. Processing area

2. Assembly area

The processing area is used for manufacturing the components, while the assembly area is meant for assembling the product.

\subsection{Value Stream Mapping}

Value stream mapping, a lean manufacturing tool originated from the TPS, is known as "material and information flow mapping." This mapping tool uses lean manufacturing to analyze and evaluate certain work processes in manufacturing operation. This tool is used primarily to identify, demonstrate and decrease waste, as
*Corresponding Author: mfaerofaizal3@gmail.com

Received: 12.10.2017 Accepted: 25.11.2017 Published on: 12.12 .2017 
well as create flow in the manufacturing process. The creation of a VSM is divided into five basic steps:

-Identify the product.

- Create a current VSM.

-Evaluate the current map, identify problem areas.

- Create a future state VSM.

-Implement the final plan.

Once you have changed the current process to minimize problem areas completely, you can create a final state VSM [9]. The last step of the value stream mapping process is to implement the new ideas, which will in turn create a more efficient lean manufacturing process.

\section{OPTIMIZING TRANSPORTATION COST}

The aim is to reduce the transportation cost that occur during the transportation of the impact bars from Harihar Alloys to the five outsourcing destination and from the outsourcing industries back to Harihar Alloys. Harihar alloys were a major contractor for 4 industries. They are the main suppliers of valves for the boilers and pipelines used in petroleum industries.

It is necessary to outsource some of their work in order to achieve their demands. Here some of the transportation costs for various industries as shown in Table A.1. Further the supply and demand for various industries is also listed as in Table A.2.

The optimization of Transportation cost using Solver tool is carried out by the given data [10]. Hence we obtain our required demand and inventory values which can be supplied from various outsourcing units in order to reduce the cost and have an efficient supply chain among the industries shown in Fig. A.1.

A simple linear programming model is constructed mathematically with the supply and demands as constraints. This model is used to optimize the transportation cost with the aid of solver tool. Hence the obtained optimized cost results about Rs.17270.

The order can be given as follows:

-Outsourcing unit A - Company A (390 components)

-Outsourcing unit B - $\quad$ Company B (390 components)

Company C (10 components)

-Outsourcing unit C - Company D (240 components) -Outsourcing unit D - $\quad$ Company E (275 components) Outsourcing unit $\mathrm{E}$ is avoided since its transportation cost is very high compared to the other units. The remaining 695 components are kept as inventories for future demand. This optimized transportation cost of Rs.17270 is achieved by following the above order for satisfying the demand.

Hence the transportation charges can be reduced when the optimized result is implemented in the industry. However the outsourcing can also be avoided in order to get rid of transport cost for which the limit and the answer report is as shown in Fig.A.2 and Fig.A.3.

\section{OVERALL FLOW PROCESS SIMULATION}

The process flow is simulated using simulation software. In this flow process, Harihar Alloys supplies valves for four different customers. It starts with the order from the customers and then the order is processed according to their specification. The duration for each process is given as inputs for the simulation as shown in Table A.3.

The valves are manufactured using the sand casting process where a predefined pattern of various valves should be prepared shown in Fig. A.4. It involves moulding process where the mould is made with the help of the preexisting pattern.

Once the moulding is done the molten metal is poured into the sand moulding flask. The slow cooling of the casting part which takes a time of around 3-4 hrs is performed. Then it is passed to the fettling zone where the removal of burn-out sand deposited in the surface of the casted material and some extra projections in it. It takes around 30-40 minutes. Now these components are sent to another industry for machining. The entity report is describes as shown in Fig A.5. In this section the appropriate dimensional requirement are obtained using various machining process which takes around 2-3 hrs.

At last the components are sent to five different outsourcing units where the surface finish process is carried out in order to maintain the dimensional accuracy and aesthetic surface appearance. Then some inspections are carried in order to assure the quality that the customer requires. The Queue report of this simulation is as shown in Fig. A.6.

Now the packing is done and the components are dispatched to various customers. These processes are simulated in detail along with their cycle time for each process from start to end as shown in Fig A.7.

\section{VALUE STREAM MAPPING FOR THE PROCESSES}

Value stream mapping, a lean manufacturing tool, which originated from the TPS, is known as "material and information flow mapping." This mapping tool uses the techniques of lean manufacturing to analyse and evaluate certain work processes in a manufacturing operation. Here various customers will order upon their required products from the industry and the industry will process with various flow orders along the inventories and transporting methodologies between various departments.

The current state mapping represents the traditional method followed in the industry as shown in Fig. A.8. But the future state mapping represents an improved condition with more number of alternatives that provides better productivity than before with less lead time thereby minimizing the Non-value added time in the overall process as shown in Fig.A.9.

Some of the inputs are:

Demand $=50$ Nos.

Work Time $=480$ minutes

Takt Time $=9.60$ minutes

\section{RESULTS AND DISCUSSION}

The solver tool is used to optimize the transportation cost involved in between the routes. The optimized cost results about Rs.17270. Hence the transportation charges can be reduced when the optimized result is implemented in the industry.

The overall flow process is simulated which results in the number of components produced per day is 64 . A value stream map is drawn for the current state of the industry and it is improvised with some alternatives to reduce the lead time and increase the productivity in the future state mapping. This alternative reduces the lead time from 431.60 minutes to 345.20 minutes and the Non-Value Added Time is reduced from 1.60 minutes to 20 seconds. 
Table 1 Transportation cost

\begin{tabular}{|c|c|c|c|c|}
\hline & $\begin{array}{c}\text { BHEL } \\
\text { TRICHY } \\
\text { (Rs.) }\end{array}$ & $\begin{array}{c}\text { BHEL } \\
\text { VELLORE } \\
\text { (Rs.) }\end{array}$ & $\begin{array}{c}\text { RANE } \\
\text { TRICHY } \\
\text { (Rs.) }\end{array}$ & $\begin{array}{c}\text { SUNMAR } \\
\text { FORGING } \\
\text { (Rs.) }\end{array}$ \\
\hline A & 8 & 40 & 10 & 10 \\
\hline B & 12 & 32 & 10 & 8 \\
\hline C & 15 & 45 & 18 & 8 \\
\hline D & 10 & 30 & 12 & 12 \\
\hline E & 12 & 40 & 15 & 8 \\
\hline
\end{tabular}

Table 2 Availability and Demand

\begin{tabular}{|c|c|c|c|c|c|}
\hline Availability & 400 & 400 & 400 & 400 & 400 \\
\hline Demand & 390 & 275 & 390 & 250 & 695 \\
& & & & & \\
\hline
\end{tabular}

Table 3 Duration of various processes

\begin{tabular}{|c|c|c|}
\hline S.No. & Process & Duration \\
\hline 1 & Sand casting & $3-4$ hrs \\
\hline 2 & Fettling & $30-40$ minutes \\
\hline 3 & Machining & $2.5-3$ hrs \\
\hline 4 & Surface Finish & 2 hrs \\
\hline 5 & Impact Testing & 20 minutes \\
\hline 6 & Packing & 20 minutes \\
\hline
\end{tabular}

Figure A.1. Optimization using MS-Excel Solver

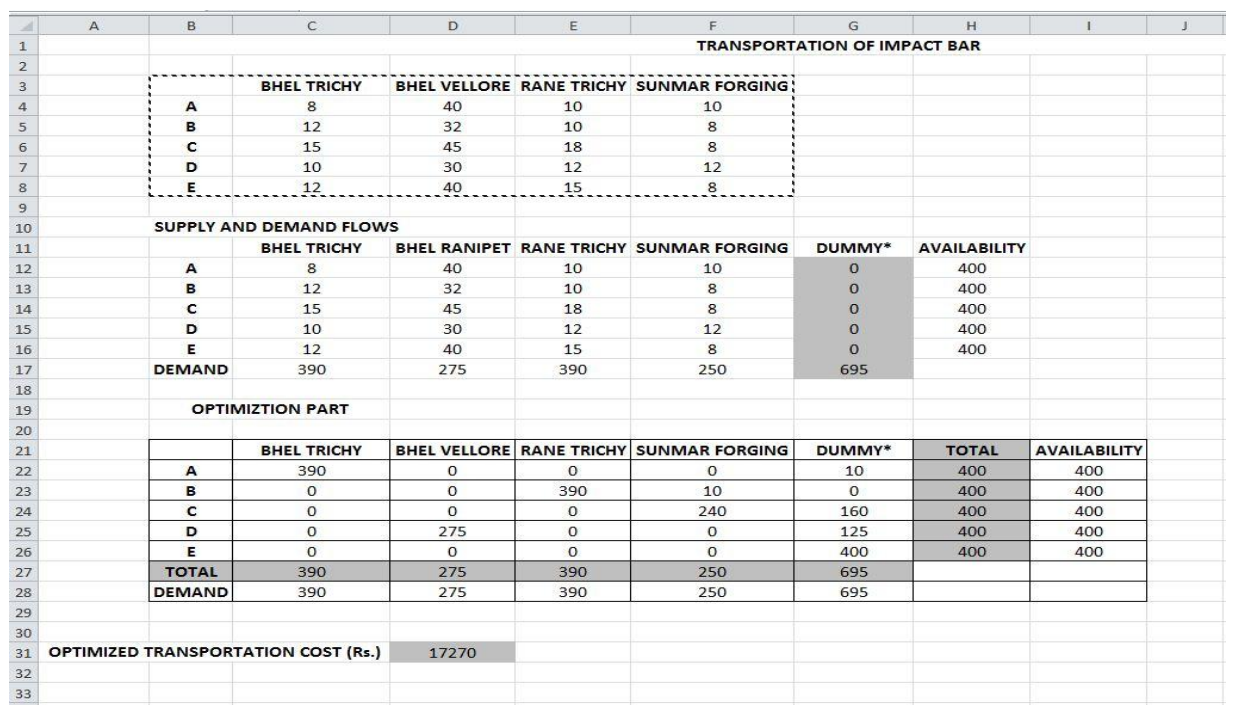




\begin{tabular}{|c|c|c|c|c|c|}
\hline Name & $\begin{array}{l}\text { Final } \\
\text { Value }\end{array}$ & $\begin{array}{c}\text { Reduced } \\
\text { Cost }\end{array}$ & $\begin{array}{l}\text { Objective } \\
\text { Coefficient }\end{array}$ & $\begin{array}{l}\text { Allowable } \\
\text { Increase }\end{array}$ & $\begin{array}{l}\text { Allowable } \\
\text { Decrease }\end{array}$ \\
\hline \multicolumn{6}{|l|}{ SBS22:SF\$26 } \\
\hline SBS22 A BHEL TRICHY & 390 & 0 & 8 & 2 & $1 E+30$ \\
\hline$\$ C \$ 22$ A BHEL VELLORE & 0 & 10 & 40 & $1 \mathrm{E}+30$ & 10 \\
\hline SD\$22 A RANE TRICHY & 0 & 0 & 10 & $1 \mathrm{E}+30$ & 0 \\
\hline \$ES22 A SUNMAR FORGING & 0 & 2 & 10 & $1 E+30$ & 2 \\
\hline SF\$22 A DUMMY- & 10 & 0 & 0 & 0 & 2 \\
\hline SBS23 B BHEL TRICHY & 0 & 4 & 12 & $1 \mathrm{E}+30$ & 4 \\
\hline SC\$23 B BHEL VELLORE & 0 & 2 & 32 & $1 \mathrm{E}+30$ & 2 \\
\hline SD\$23 B RANE TRICHY & 390 & 0 & 10 & 0 & $1 E+30$ \\
\hline \$E\$23 B SUNMAR FORGING & 10 & 0 & 8 & 0 & 0 \\
\hline SF\$23 B DUMMY- & 0 & 0 & 0 & $1 \mathrm{E}+30$ & o \\
\hline SBS24 C BHEL TRICHY & 0 & 7 & 15 & $1 E+30$ & 7 \\
\hline \$C\$24 C BHEL VELLORE & 0 & 15 & 45 & $1 E+30$ & 15 \\
\hline SD\$24 C RANE TRICHY & 0 & 8 & 18 & $1 \mathrm{E}+30$ & 8 \\
\hline SES 24 C SUNMAR FORGING & 240 & 0 & 8 & 0 & 0 \\
\hline SF\$24 C DUMMY- & 160 & 0 & 0 & 0 & 0 \\
\hline \$B\$25 D BHEL TRICHY & 0 & 2 & 10 & $1 \mathrm{E}+30$ & 2 \\
\hline SC\$25 D BHEL VELLORE & 275 & 0 & 30 & 2 & $1 E+30$ \\
\hline SDS25 D RANE TRICHY & 0 & 2 & 12 & $1 E+30$ & 2 \\
\hline SES25 D SUNMAR FORGING & 0 & 4 & 12 & $1 E+30$ & 4 \\
\hline SF\$25 D DUMMY- & 125 & 0 & 0 & 2 & 2 \\
\hline SBS26 E BHEL TRICHY & 0 & 4 & 12 & $1 E+30$ & 4 \\
\hline SCS26 E BHEL VELLORE & 0 & 10 & 40 & $1 E+30$ & 10 \\
\hline \$D\$26 E RANE TRICHY & 0 & 5 & 15 & $1 \mathrm{E}+30$ & 5 \\
\hline SE\$26 E SUNMAR FORGING & 0 & 0 & 8 & $1 \mathrm{E}+30$ & 0 \\
\hline SF\$26 E DUMMY- & 400 & 0 & 0 & 0 & $1 \mathrm{E}+30$ \\
\hline \multicolumn{6}{|l|}{ Constraints } \\
\hline Cell $\quad$ Name & $\begin{array}{l}\text { Final } \\
\text { Value }\end{array}$ & $\begin{array}{l}\text { Shadow } \\
\text { Price }\end{array}$ & $\begin{array}{l}\text { Constraint } \\
\text { R.H. Side }\end{array}$ & $\begin{array}{l}\text { Allowable } \\
\text { Increase }\end{array}$ & $\begin{array}{l}\text { Allowable } \\
\text { Decrease }\end{array}$ \\
\hline SBS27 TOTAL BHEL TRICHY & 390 & 8 & 390 & 0 & 160 \\
\hline SC\$27 TOTAL BHEL VELLORE & 275 & 30 & 275 & 0 & 160 \\
\hline SDS27 TOTAL RANE TRICHY & 390 & 10 & 390 & 0 & 240 \\
\hline SES27 TOTAL SUNMAR FORGINE & 250 & 8 & 250 & o & 240 \\
\hline SF\$27 TOTAL DUMMY - & 695 & 0 & 695 & 0 & 160 \\
\hline SGS22 A TOTAL & 400 & 0 & 400 & 160 & 0 \\
\hline SGS23 B TOTAL & 400 & 0 & 400 & 240 & 0 \\
\hline \$G\$24 C TOTAL & 400 & 0 & 400 & 0 & $1 E+30$ \\
\hline SG\$25 D TOTAL & 400 & 0 & 400 & 160 & 0 \\
\hline SG\$26 E TOTAL & 400 & 0 & 400 & 160 & 0 \\
\hline
\end{tabular}

Figure A.2. Limits Report

\begin{tabular}{|c|c|c|c|c|}
\hline cell & Name & Original Value & Final Value & Integer \\
\hline \multicolumn{5}{|c|}{ \$B\$22:\$F\$26 } \\
\hline$\$ 3 \$ 22$ & A BHEL TRICHY & 1 & 390 & Contin \\
\hline$\$ c \$ 22$ & A BHEL VELLORE & 2 & 0 & Contin \\
\hline$\$ 0 \$ 22$ & A RANE TRICHY & 6 & 0 & contin \\
\hline SE\$2Z & A SUNMAR FORGING & 1 & 0 & Contin \\
\hline \$F\$22 & A DUMMY* & 6 & 10 & contin \\
\hline$\$ B \$ 23$ & B BHEL TRICHY & 5 & 0 & Contin \\
\hline $50 \$ 23$ & B BHEL VELLORE & 2 & 0 & contin \\
\hline$\$ 0 \$ 23$ & B RANE TRICHY & 2 & 390 & contin \\
\hline SES23 & B SUNMAR FORGING & 7 & 10 & Contin \\
\hline$\$ F \$ 23$ & B DUMMY* & 8 & o & contin \\
\hline$\$ B \$ 24$ & C BHEL TRICHY & 4 & 0 & contin \\
\hline$\$ c \$ 24$ & C BHEL VELLORE & 1 & o & Contin \\
\hline$\$ 0 \$ 24$ & C RANE TRICHY & 2 & o & Contin \\
\hline SES 24 & C SUNMAR FORGING & 8 & 240 & contin \\
\hline SF\$24 & CDUMMY & 5 & 160 & Contin \\
\hline$\$ 8 \$ 25$ & D BHEL TRICHY & 4 & 0 & Contin \\
\hline$\$ c \$ 25$ & D BHEL VELLORE & 2 & 275 & Contin \\
\hline$\$ D \$ 25$ & D RANE TRICHY & 7 & 0 & Contin \\
\hline SE\$2S & D SUNMAR FORGING & 9 & o & contin \\
\hline SF\$25 & D DUMMY* & 4 & 125 & contin \\
\hline$\$ B \$ 26$ & E BHEL TRICHY & 1 & 0 & contin \\
\hline$\$ c \$ 26$ & E BHEL VELLORE & 4 & 0 & contin \\
\hline$\$ D \$ 26$ & E RANE TRICHY & 5 & o & contin \\
\hline SE\$26 & E SUNMAR FORGING & 4 & o & Contin \\
\hline$\$ F \$ 26$ & E DUMMY* & 5 & 400 & contin \\
\hline
\end{tabular}

\begin{tabular}{|c|c|c|c|c|c|}
\hline cell & Name & Cell Value & Formula & Status & Slack \\
\hline$\$ 8 \$ 27$ & TOTAL BHEL TRICHY & 390 & $\$ B \$ 27=\$ B \$ 28$ & Binding & 0 \\
\hline$\$ c \$ 27$ & TOTAL BHEL VELLORE & 275 & $\$ c \$ 27=\$ c \$ 28$ & Binding & o \\
\hline \$D\$27 & TOTAL RANE TRICHY & 390 & $\$ D \$ 27=\$ D \$ 28$ & Binding & o \\
\hline SE\$27 & TOTAL SUNMAR FORGING & 250 & $\$ E \$ 27=\$ E \$ 28$ & Binding & o \\
\hline$\$ F \$ 27$ & TOTAL DUMMY* & 695 & $\$ F \$ 27=\$ F \$ 28$ & Binding & o \\
\hline$\$ G \$ 22$ & A TOTAL & 400 & $\$ G \$ 22=\$ H \$ 22$ & Binding & 0 \\
\hline$\$ G \$ 23$ & B TOTAL & 400 & $\$ G \$ 23=\$ H \$ 23$ & Binding & $\mathbf{o}$ \\
\hline$\$ G \$ 24$ & C TOTAL & 400 & $\$ G \$ 24=\$ H \$ 24$ & Binding & o \\
\hline$\$ G \$ 25$ & D TOTAL & 400 & $\$ G \$ 2 S=\$ H \$ 2 S$ & Binding & o \\
\hline$\$ G \$ 26$ & E TOTAL & 400 & $\$ G \$ 26=\$ H \$ 2 E$ & Binding & o \\
\hline
\end{tabular}

Figure A.3. Answer Report 


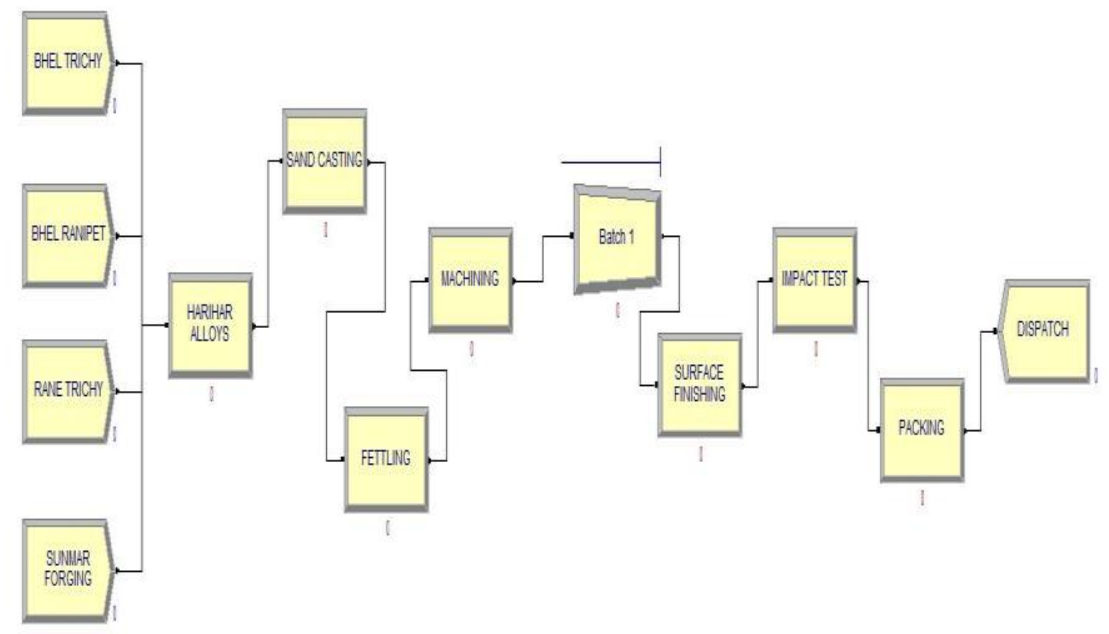

Figure A.4. Simulation of the manufacturing process flow using ARENA

\begin{tabular}{|c|c|c|c|c|}
\hline Entity & & & & \\
\hline \multicolumn{5}{|l|}{ Time } \\
\hline VA Time & Average & Half Wiath & $\begin{array}{c}\text { Minimum } \\
\text { Value }\end{array}$ & $\begin{array}{c}\text { Maximum } \\
\text { Value }\end{array}$ \\
\hline Entity 1 & 78.2112 & (Insufficient) & 72.3887 & 84.1904 \\
\hline NVA Time & Aversge & Half Wioth & $\begin{array}{l}\text { Minimum } \\
\text { Value }\end{array}$ & $\begin{array}{c}\text { Maximum } \\
\text { Value }\end{array}$ \\
\hline Entity 1 & 0.00 & (Insufficient) & 0.00 & 0.00 \\
\hline Wait Time & Aversoge & Half Wioth & $\begin{array}{c}\text { Minimum } \\
\text { Velue }\end{array}$ & $\begin{array}{l}\text { Maximum } \\
\text { Velue }\end{array}$ \\
\hline Entity 1 & 30.3008 & (Insufficient) & 0.9760 & 182.69 \\
\hline Transfer Time & Average & Half Width & $\begin{array}{c}\text { Minimum } \\
\text { Value }\end{array}$ & $\begin{array}{c}\text { Maximum } \\
\text { Value }\end{array}$ \\
\hline Entity 1 & 0.00 & (Insufficient) & 0.00 & 0.00 \\
\hline Other Time & Average & Half Wiath & $\begin{array}{c}\text { Minimum } \\
\text { Value }\end{array}$ & $\begin{array}{c}\text { Maximum } \\
\text { Value }\end{array}$ \\
\hline Entity 1 & 0.00 & (Insufficient) & 0.00 & 0.00 \\
\hline Total Time & Average & Half Width & $\begin{array}{c}\text { Minimum } \\
\text { Value }\end{array}$ & $\begin{array}{l}\text { Maximum } \\
\text { Value }\end{array}$ \\
\hline $\begin{array}{l}\text { Entity } 1 \\
\text { Other }\end{array}$ & 16.7148 & (Insufficient) & 10.3423 & 34.6173 \\
\hline Number in & value & & & \\
\hline Entity 1 & 704.00 & & & \\
\hline Number Out & value & & & \\
\hline Entity 1 & 704.00 & & & \\
\hline WIP & Average & Half Width & $\begin{array}{l}\text { Minimum } \\
\text { value }\end{array}$ & $\begin{array}{c}\text { Maximum } \\
\text { value }\end{array}$ \\
\hline Entity 1 & 19.2204 & (Insufficient) & 0.00 & 44.0000 \\
\hline
\end{tabular}

Fig A.5. Entity Report 


\begin{tabular}{|c|c|c|c|c|}
\hline \multicolumn{5}{|l|}{ Queue } \\
\hline \multicolumn{5}{|l|}{ Time } \\
\hline Waiting Time & Aversge & Half With & $\begin{array}{l}\text { Minimum } \\
\text { Value }\end{array}$ & $\begin{array}{l}\text { Maximum } \\
\text { Value }\end{array}$ \\
\hline Batch 1.Queue & 3.0301 & (Correlated) & 0.00 & 23.2495 \\
\hline \multicolumn{5}{|l|}{ Other } \\
\hline Number Waiting & Aversge & Helf Wiath & $\begin{array}{c}\text { Minimum } \\
\text { Value }\end{array}$ & $\begin{array}{l}\text { Maximum } \\
\text { Value }\end{array}$ \\
\hline Batch 1.Queue & 4.1502 & (Correlated) & 0.00 & 10.0000 \\
\hline
\end{tabular}

Fig A.6. Queue Report

\begin{tabular}{lcc} 
08:38:26PM & Category Overview & February 21, 2016 \\
\hline Unnamed Project & \\
\hline Replications: $1 \quad$ Time Units: & Hours \\
& Key Performance Indicators \\
System & Average \\
Number Out & 64
\end{tabular}

Fig A.7. Key performance indicator

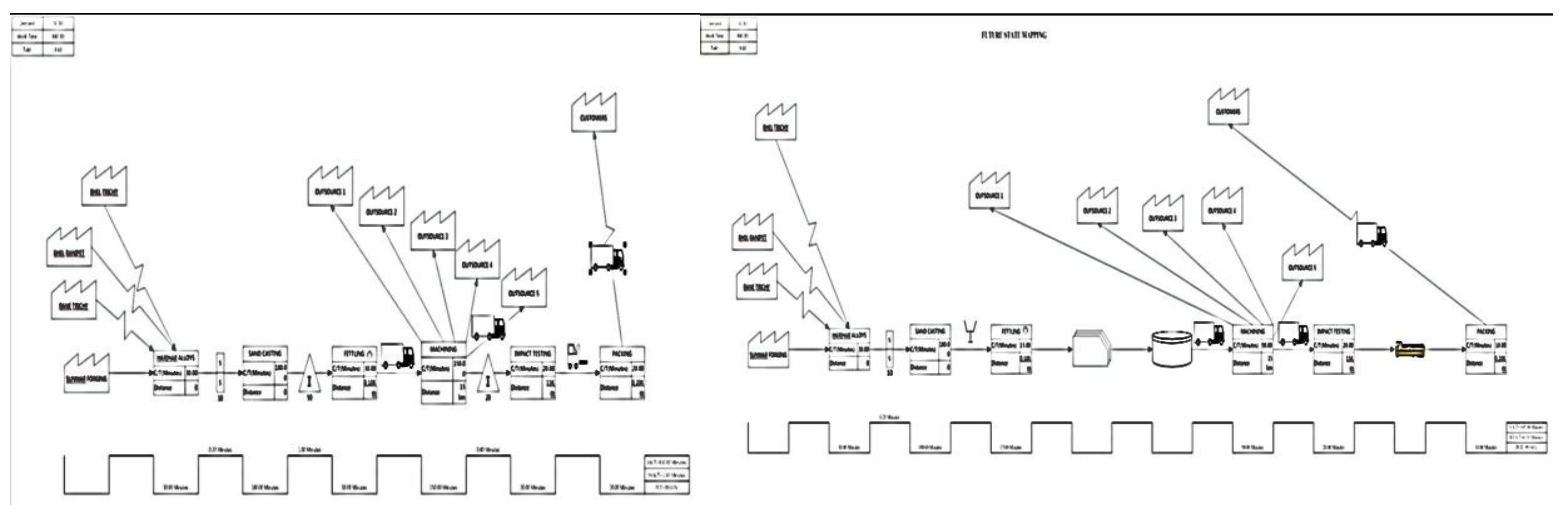

Fig A.8. Current State Mapping

Fig A.9. Future State Mapping 


\begin{tabular}{|c|c|}
\hline Current State: & \\
\hline Lead Time & $=431.60$ minutes \\
\hline Value Added Time & $=430$ minutes \\
\hline Non-Value Added Time & $=1.60$ minutes \\
\hline Future State: & \\
\hline Lead Time & $=345.20$ minutes \\
\hline Value Added Time & $=345$ minutes \\
\hline Non-Value Added Time & $=20$ seconds \\
\hline
\end{tabular}

\section{CONCULSION}

It is concluded that the optimization of the transportation cost is done and the obtained effective solution can be implemented to get improved results. Further, more number of transportation data can be collected and a detailed study is made to acquire more appropriate results for the betterment of transportation cost. In case of manufacturing process, the performance can be improved the installing more number of machineries and employing skilled and efficient workers. For value stream mapping the future state mapping with some alternatives provides good reduction in the overall lead time and non-value added time compare to the current state mapping. Hence future studies can be made more in detail about the cycle time for each process with the help of time study and work study to obtain more accurate solutions.

\section{REFERENCES}

[1]. Andrii Halkin, Vasyl Skrypin, Evgen Kush, Kateryna Vakulenko, Viktor Dolia, 2017, Invest Approach to the Transportation Services Cost Formation, 16th Conference on Reliability and Statistics in Transportation and Communication, 178, 435 - 442.

[2]. MstNazma Sultana, Shohanuzzaman Shohan, Fardim Sufian, 2014, Aggregate Planning Using Transportation Method: A Case Study In Cable Industry, International Journal of Managing Value and Supply Chains, 5, 215234.

[3]. Muztoba Ahmad Khan, 2014, Transportation Cost Optimization Using Linear Programming, International Conference on Mechanical, Industrial and Energy Engineering, 2241-2245.

[4]. Ilija Nikolic, 2007, Total Time Minimizing Transportation Problem, Yugoslav Journal of Operations Research, 17, 125-133.

[5]. Nonihal Singh Dhakry, Ajay Bangar, 2013, Minimization of Inventory \& Transportation Cost of an Industry-A Supply Chain Optimization, 3, 96-101.

[6]. Ioana Monica Sas-Boca, Marius Tintelecan, Mariana Pop, Dana-Adriana Ilutics - Varvara, Ardina Maria Mihu, 2017, The Wire drawing process simulation and the optimization of geometric dies, 10th International Conference Interdisciplinarity in Engineering, 181, 187-192.

[7]. Luis Felipe Riehs Camargo, Luis Henrique Rodrigues, Daniel Pacheco Lacerda, Fabio Sartori Piran, 2017, A Method for Integrated Process Simulation in the Mining Industry, European Journal of Operation Research, 3, 4-48.
[8]. Ratheesh PG, 2015, Standardization of Work in a Manufacturing Industry, International Research Journal of Engineering and Technology, 2, 997-999.

[9]. Wolfgang Apel, Jia Yong Li, Vanessa Walton, 2007, Value Stream Mapping for Lean Manufacturing Implementation, Thesis report for Worcester Polytechnic Institute and Central Industrial Supply, 4, 9-16.

[10]. Hossam A. Gabbar, Raymond Bedard, Nasser Ayoub, 2016, Integrated Modeling for Optimized Regional Transportation with Compressed Natural Gas Fuel, Alexandria Engineering Journal, 55, 533-545. 